\title{
AZ ÉPÍTÉSZETI KRITIKÁRÓL GONDOLATTÖREDÉKEK
}

\author{
SZALAI ANDRÁS*
}

A gondolatok a szellem testesülései. A szellem válhat szóvá és lehet formává is. A gondolkodás a „szellemi létezőkkel” való érintkezés területe, a szavak és a formák keletkezésének birodalma.

A gondolkodás során a szavak fogalmakat szülnek, s ezek konfigurációjaként válnak ábrázolhatóvá az ideák, vagyis a „lényegiségek”, „szellemi létezők”, melyek az „igazságot” mint szándék nélküli létet alkotják. A formát eredményező gondolatok is az ideák ábrázolására törekszenek - valamely ideához hasonlatos, végleges alakot alkotva a mindenkori jelenben -, „szépségként” jelenítve meg az „igazságot”. Az ideák világának ekképpen való - Walter Benjamin felfogása szerinti - szóbeli és/vagy képi-formai ábrázolása voltaképpen poézis (poiészisz), azaz „készítés” vagy „létrehozás”, ahol az igazság szépségként van jelen, a szépséget pedig annak igazsága hitelesíti [1].

Mindez a hajdan létező sensus communis - közös érzékelés és ízlés - fennállása idején, annak védőernyője alatt magától értetődő módon tűnhetett érvényesnek. A sensus communis szétesésének következtében azonban az igazság és a szépség - a jó fogalmával együtt - önállóvá vált, majd megkérdőjeleződött a poézis „,tisztasága", és az is kiderült, hogy a formára csak rámutatni tudunk, miközben olykor úgy tünik, hogy a szavak és a formák kifejező ereje is apránként elenyészik.

Az általános elvek bizonytalanná válása az egyetemes törvénytan megingása a (művészi) formaalkotásra és az ezzel kapcsolatos teóriára is kihat. „Ilyenkor megnő a kritika rangja és súlya. Nem másodlagos, alkalmazott, hanem elsődleges, lehetséges teória. Nem végpont egy létező teóriában, de kiindulópont egy létrehozandó teóriához. Éppen a kritika lehetőségei miatt érdemes pontosítani. Nem a történelem és benne létünk eredendő történetiségére vonatkozó magyarázatok lettek kérdésesek. A mú ma is történeti produktum, históriai sorsot hordozó üzenet és művészi ítélet. Csupán történeti produktum voltának, históriai sorsot hordozó üzenetének és művészi ítéletének értelmezése szorul újragondolásra. Hitelét vesztett

* Budapesti Műszaki és Gazdaságtudományi Egyetem, Építészmérnöki Kar, Építészettörténeti és Műemléki Tanszék. 1111 Budapest, Műegyetem rkp. 3. K. II. 60. Tel.: 463-1330; fax: 463-1638 
régi sémák után hitelesíthető új gondolatmenetekre. Tények és összefüggések érzékeny és elméletileg pontos néven nevezésére. Konkrétabb, de töprengőbb, utópiáktól mentes, de hitektôl nem mentes megfogalmazásokra" [2].

A nehézségeket azonban nem csupán az a már-már közhelyszerü és közismert tény jelenti, hogy korunkban az értékek felismerése egyre nehezebb, mert relativizálódott az értékrend és következésképpen nincsenek érvényes esztétikai normák. Csökkenni és erejét veszíteni látszik az a szellemi energia is, amely egy adott kor vizuális-plasztikai-architektonikus gondolkodásmódjának nem pusztán tükrözője, de generálója is volt. Ennek a művészi törekvéseket szervező és homogenizáló erőnek, szellemi energiának a belső demiurgosza - jószerivel a huszadik század elejéig-közepéig - a Kunstwollen volt, aminek lényegét Wölfflin tömören így fogalmazta meg: „Nem minden lehetséges minden korban.” Amíg müködtek olyan erôk, melyeket efféle belső logika vezérelt, addig a kritikusnak ezek mechanizmusát kellett felismernie, észrevennie, a jelenségekben munkálkodó szükségszerú vonásokat, s ezzel a mércével minősíthette az egyes műveket, hiszen azok „,immanens poétikája” kötődött a „múvészetakarás” lényegéhez és mozgásirányához.

Ha azonban ,a nem minden lehetséges minden korban” addig törvényszerünek tűnő belső logikáját a „,minden lehetséges” állapota váltja fel, akkor a múvészi törekvéseket már nem belső erő vezérli, hanem külső manipuláció, aminek következményeit Németh Lajos így összegezte: „A regulatív szerepet játszó, viszonylag homogén vizuális-plasztikai(-architektonikus) „köznyelv” megroppanása, a Kunstwollen energiájának csökkenése tehát a „minden lehetséges” állapotához vezetett, ennek pedig szinonimája a „minden mindegy”, vagy más szavakkal az autentikusság elvesztése, hiszen autentikus csak az lehet, aminek belső vezérlő elve, logikája van. Az egzisztenciál-filozófia kérdésfeltevésénél vagyunk tehát, a nem autentikus és az autentikus lét problémakörénél, s úgy tűnik, hogy a múvészet nagy egészében a nem autentikus lét szférájába került, s csak nagyon kevesen tudják a sodrából kivonni magukat.

A művészet azonban, bármilyen dinamikus tényező is, mégis csak egy összetevője a kulturális mezőnek, s az, hogy a banalitásvilág tartozékává vált, elveszítette autentikusságát, sejteti, hogy hasonló folyamat játszódott le a kultúra egyéb területein is. A kultúrszociológusok számtalan analízisben mutattak rá erre bizonyítván, hogy a kultúra, e szimbólumokat hordó struktúra korábban intézményesítve volt, most valójában konzumálva van, a szimbolizációt a fetisizáció váltotta fel. A mítosz és a rítus csupán pszeudoszinten vegetál, a mítoszok azonnal konzumálódnak, illetve nem autentikus mítoszok és rítusok születnek. A rituális cselekvésformák, a ceremóniák is elvesztik autentikusságukat - és folytatni lehetne a kórleletek sorolását. Mindez arra utal, hogy nem pusztán a Kunstwollen zavarodott meg, hanem a modern társadalom egész expresszív kulturális rendszere" [3]. 
A modern (és modern utáni) kor expresszív kulturális rendszerének megroppanását észleli a „közönyös paroxista”, Jean Baudrillard is, amikor arról beszél, hogy a minden érték átértékelésének nietzschei gondolata nem a jón és a rosszon, az igazon és a hamison, a szépen és a csúfon való túljutás formájában valósult meg, hanem innen maradva rajtuk, az értékek visszafejlődésének formájában. „Nem átváltozás, meghaladás történt, hanem felbomlás és elmosódás. (...) Az értékek mind kancsallá váltak. Nagyon messzire kerültünk attól, hogy az értékek feszültségéből és folytonos egymásnak ütközéséből valamiféle értéktöbblet jöjjön létre... Amikor a hamis felhasználja az igaz összes energiáját, vagy fordítva, az az illúzió. Amikor a reális felszívja az irreális összes energiáját, az a fikció. Ezzel szemben viszont, amikor az igaz elveszíti még a fordított, imaginárius energiáját is, az a szimuláció, vagyis az illúzió legalacsonyabb foka. Amikor a jó még a rossz energiáját is elveszíti, az az erkölcs legalacsonyabb foka" [4].

Ebben a már-már fokozhatatlanul bizonytalan helyzetben alkotónak is, kritikusnak is, úgy tűnik, egyetlen lehetősége maradt: „muszáj-herkulesként” törekedni az autenticitásra, tudva, hogy minden mü és minden lehetséges értékelés, értelmezés megköveteli ezt, hiszen miután véget ért - Heideggerrel szólva - „a létfeledtség története”, szinte minden, ami korábban „csak” feladat volt - a történelem, a művészet, az építészet és a nyelv is - problémává vált.

\section{2.}

A hajdan volt sensus communis érvényessége idején az építészetről traktátusokat írtak. A könyvekben kifejezett értekezésekben megjelenő teóriát, ami a praxis bizonyos vonatkozásait is magába foglalta, az elődökre, tekintélyekre és a hagyományokra való hivatkozás alapozta meg. A teóriát az ideák szemlélése jelentette. Amikor a szép és a művészet - benne magától értetődően az építészet - mibenléte önmagában és jóhoz, igazhoz való viszonyában is (bölcseleti) magyarázatra szorult, az építészet értelmezését látnoki, utópikus-múvészeti-esztétikai értelemben „forradalmi” - szemlélet kezdte áthatni. Az első látnokok szándéka még az volt, hogy hidat verjenek a múlt és a jövő között. A traktátusok - miközben szerzőik tekintetüket az ideákra irányították - tárgyalták témájukat, az építészetet. Az esszék - mivel szerzőik már nem voltak meggyőződve a régi ideák érvényességéről - tanulmányozni, vizsgálni kezdték témájukat, az építészetet.

A mítikus alapokon létező régi ideákat (értékeket) később felváltotta a történelem mítosza. A történelem mitikus felfogása, a historicizmus teremtette meg az alapot új ideák létrehozására. Ekkor születtek a történelem tanulmányozásában gyökerező átfogó tárgyalások, melyek az eredet vizsgálatát célozták meg, hogy közelebb kerüljenek az építészet korok feletti lényegéhez, hogy megfejthessék a 
fejlődés irányát, meghatározzák a kor(ok) szellemét. Az enciklopédikus, historicista alapokon az építészetet vizsgáló tárgyalásmód azonban úgy tünt, hogy nem kínált közvetlenül alkalmazható „cselekvési programot” az építészek számára. Szükségesnek látszott a konkrét cselekvés, az ideák szemlélése helyett új ideák létrehozása, amit az építészek, hasonlóan az ,idő ormait ostromló” többi avantgard művészhez, kiáltványokban, kiáltványszerű deklaratív írásokban öntöttek formába.

Az új ideákat létrehozni akaró modernitással az építészetben is berekesztődött a „létfeledtség kora”, ami e „királyi múvészetet” is újdonságfüggővé változtatta úgy, hogy (mindenkori) aktuális kulturális identitását is ennek függvényeként határozta meg; mondván: ,,azért értékes, mert korszerü!” A huszadik század építészetének történetét és teóriáit, valamint formaalkotó törekvéseit is, mintha ez az imperatívusz hatotta volna át és határozta volna meg még akkor is, amikor a posztmodern a modernizmus redukcionizmusával a maga jelentésteliséget szimuláló eklekticizmusát állította szembe. Holott korszerüség és érték - erre figyelmeztetett annakidején Fülep Lajos is, éppen az építészet példájával -, nem feltétlenül esnek egybe: „Nem azért értékes, mert korszerü, hanem azért korszerü, mert értékes” [5].

A huszadik századi építészetben bekövetkezett - néha túl gyors - paradigmaváltások és a sokféle, egyszerre fennálló és egyaránt érvényesnek minősülő paradigma csak részben szolgáltathat magyarázatot erre az állapotra, vagyis korszerüség és érték fordított módon egyirányú viszonyára. Hiszen mindennemú pluralizmus ellenére - ami nem csupán annyi, hogy ,'́gy is lehet, úgy is lehet” - az építészeti alkotás (is) végsoron formaalkotás, ahol minden forma mögött alkotói döntés húzódik, ahol a formának aktív, értékteremtő szerepe van. „A művészet konkrét állapítja meg Fülep - A korszerüség követelménye tehát nem a divaté, s nem is a 'haladni a korral', hanem pótolhatatlan, mással helyettesíthetetlen lehetőség" [6]. A múvészet is, hasonlatosan a filozófiához, voltaképpen a kor tudatosítása.

A forma aktív értékteremtő szerepe tehát azt jelenti, hogy a mű rangjára igényt tartó épület mint bonyolult formai képződmény - Németh Lajos megfogalmazásával élve -, „nem csupán jelentésstruktúra, hanem jelentéssel bíró értékstruktúra” is, jóllehet a közelmúlt interpretációs modelljei mintha zárójelbe tették volna a müvészi érték kérdését, annak ellenére, hogy a müvészeti - esztétikai jelentés mindig értékminőség.

Jelentés és érték viszonyának értelmezését az építészetben - az alkotás és az interpretáció vonatkozásában egyaránt - az is nehezíti, hogy az építészeti formák esetében csak fenntartásokkal lehet vizuális kódokról beszélni. A legtöbb építészeti formának, elemnek nincs szavakkal is megfogalmazható jelentése. Jelentésük elsősorban kontextuális, azaz többnyire azonos használatukkal, expresszivitásukkal. Ezt a expresszivitást viszont a mű, az épület „képződményszerü jelenléte” képes igazán érvényre juttatni, hiszen a mű mint „,képződmény” célja elsősorban nem va- 
laminek - például a korszellemnek - a reprodukálása, hanem az, hogy „,valami szilárdba zárja be az értelmet úgy, hogy az (...) a képződmény struktúráltságában rögződik és ôrződik meg.” Az ekképpen „képződő” alkotás, mü jelentősége jelenlétében rejlik, benne és általa nem csupán utalás történik valamire, nem pusztán célokat szolgál, létrejötte ,a lét gyarapodását jelenti” [7].

Mindennek tudatosítása, reflektív módon való végiggondolása és újraértelmezése fontos (lehet) az alkotás során és elengedhetetlen az alkotást értelmező (kritikai) tevékenység alkalmával is, különösen az ,anything goes” értékrelativitást szuggeráló körülményei közepette, hiszen „értékpotenciállal” rendelkező (építészeti) formát, múvet létrehozni enélkül szinte csak véletlenül lehet. Az építészeti alkotásra is igaz Paul Valéry mondása: „A forma sokba kerül!”

Ebben az - itt csak felvetett - összefüggésben az építészetre is vonatkoztatható Németh Lajos múinterpretációval kapcsolatos megállapítása, miszerint ,az, hogy a müben milyen értékekről lehet szó, kortól determinált és összefügg a müvészet és a mủ konkrét funkciójával és vállalt feladatával, tehát az „immanens poétikával” is. (...) E kérdés (azonban) nem azonos azzal a lényegében szociológiai problémával, hogy egy kor mit fogad el és minősít értéknek, vagy hogy a későbbi szemlélet milyen új értéket fedez fel a müben - épp e későbbi tapasztalatok révén -, vagy pedig értékként fogad el olyan tényezőket is, amelyeket korábban nem minősítettek értéknek. Az értéktényezők értékpotenciálja ugyanis objektív, és ha az érték megvalósultságában nem is mérhető numerikusan - bár történt erre kísérlet az információesztétikában -, lehetőség van a viszonyításra, a hasonló értékpotenciálokkal való összemérésre, ez pedig egy (adott) viszonylatrendszeren belül feljogosít a rang megállapítására" [8].

Az összevetés és a rang megállapítása az értéktényezőket tekintetbevevő interpretálás, kritika eredménye lehet. Az „objektív értékpotenciál” létrehozása-maga a poézis - viszont az alkotóra és a múvére tartozik. Ugyanakkor, a vizuális-plasztikai-architektonikus gondolkodásban való (alkotói) jártasság és (kritikusi) tájékozottság mellett mindkét oldal tevékenység-reflektív, probléma-érzékeny, azaz kritikai gondolkodást követel, amihez kevés ,up-to-date” jólinformáltsággal sodródni vagy lavírozni a mindenkori aktualitás egyre magasabb hullámokat vető, de egyre sekélyebb tengerén.

3.

Ha most már az eddigieket a hazai építészetre és a honi építészeti gondolkodásra vonatkoztatottan tekintjük, akkor megállapítható, hogy ebben a közegben fokozottan érzékelhető a lehetséges teóriá(k)hoz kiindulópontot jelentő kritikai gondolkodás hiánya. Kiélezetten fogalmazva: a hazai építészetben mintha még most is csak 
„feladatok” léteznének, de „szellemi célszerüséget” (Fülep Lajos) is igénylő megoldandó és meggondolandó ,problémák” nem. A reflektivitás, a kritikai gondolkodás hiánya többek között a szórványosan nyilvánosságra kerülő alkotói ,ars poetica”-kban, „hitvallásokban” vagy ezek tapasztalható hiányában is tetten érhető. Dúlt hitekből összerótt, ki nem mondott vagy végig nem gondolt érzelmi entitásokra támaszkodó és/vagy a mindenkori aktualitás felszínébe belekapaszkodó vélekedések halmazaiból ugyanis nehezen épül olyan fundamentum, ami az alkotást és esetleg annak értelmezhetőségét is kellőképpen megalapozhatja, megalapozhatná. De hiányzik ennek a hiánynak problémaként való felmutatása is. Ugyanakkor az is kitapintható, érzékelhető, ugyancsak az érzelmi entitások szintjén, hogy eme hiányállapot problémaként való felmutatásának elmaradása a szakmának - a szórványos kivételek mintha csak a szabályt erősítenék - semmiféle hiányérzetet nem okoz.

A kritikai gondolkodás vagy annak hiánya, illetve a kritika vagy annak hiánya persze két különböző dolog. Bizonyos egymásra utaltságon túl - hiszen a kritika feltételeit a kritikai gondolkodás igénye alapozhatja meg - a kritika fogalma az, ami közös bennük.

A „kritika” és a „kriminalitás” szó a görög „krinein”-ből és a latin „,cerneré”-ből ered, amely körülbelül „törés”-t jelent, „,széttörés”, „betörés” értelemben. Vilém Flusser szerint ez a kettős jelentés már a felvilágosodás óta ismert, amikor is nyilvánvalóvá vált, hogy a kritikát a kritizált, a kritizáltat pedig a kritika tekintette bűnösnek, következésképpen az egész folyamatot már eleve áthatja a kriminalisztika légköre. A kritika eleve adott „kriminális” megítélését a magyar építészet sorsának közelmúltbeli alakulása, története, illetve e történet néhány meghatározó mozzanata csak tovább fokozta, és úgy látszik, szinte végérvényesen - elmélyítette. A szálak egészen az 1951-es, úgynevezett „,nagy építészeti vitáig” vezetnek, amikor a modern építészetet ültették ugyan a vádlottak padjára, de az ítéletből az egész szakma érthetett. Az építészek számára félreérthetetlenül üzenő vita aktusa jelképesen is a „teremtett realitások" körébe vonta, a politika egyik eszközévé változtatta az építészetet, az építészeti kritikát pedig, mint általában a kritikát, szolgáltatóvá, közvetítővé, „,politikai-ideológiai kerítővé” fokozta le. Hiszen valódi szabadság híján, valódi szellemi függetlenséget biztosító nyilvánosság nélkül - amikor a dolgok nem vitathatók meg nyilvános argumentumok révén - nincsenek valódi viták és nem írnak elfogulatlan, elemző kritikát sem. Az értelem ilyen rabságának állapotában a társadalmi szintü kényszerú-tudatos szerepjátszás folyondárja kúszik rá mindenre. Ez az állapot magában rejti azt a veszélyt, hogy túl a nyers és kusza érdekeken vagy hatalmi tusakodáson a dolgok nem annak látszanak, amik valójában, hogy elmosódik a határ ,jó” és „rossz” között, elillan a személyes felelősség, bekövetkezik az értékek eróziója. 
Mára ennek a helyzetnek a kiváltó okai végérvényesen megszüntek. Immár a kritikát sem akadályozza, befolyásolja semmilyen külső körülmény, legfeljebb csak az iránta megnyilvánuló valódi - szakmai és/vagy társadalmi - igény érzékelhető hiánya. A kritikához ugyanis nem elég egy szakma - jelen esetben az építészet - csupán reprezentatív nyilvánossága, amely csak a szakma, illetve a szakma gyakorlóinak létérdekeit képes több-kevesebb sikerrel artikulálni, de nem képes arra, hogy tényleges szakmai érdekeket érvényre juttasson ...

Mindenesetre születnek építészeti kritikák, recenziók, bár a legtöbb elsősorban egy-egy új épületről mond jó vagy rossz véleményt, s nem nagyon merészkedik ennél tágasabb mezőkre, nem evez mélyebb vizekre, ahol például már egy alkotói magatartás horizontja is látszhatna, ahol egy egész életmü mérlegre kerülhetne, megítélhetővé válna. Ennek többek között az is oka lehet, hogy ebben a kontextusban már sokkal nagyobb lenne a tét alkotói és kritikusi oldalról egyaránt. (Esetleg az életmü kapcsán kiderülne, hogy a király meztelen - botrány! -, vagy esetleg az interpretációról bizonyosodna be, hogy súlytalan apologetika - szégyen! -, tehát nem érdemes sem ezt, sem azt kockára tenni, és különben is minek, ha csak létérdekek vannak.)

Mindezt figyelembe véve azok, akik több-kevesebb sikerrel, ritkán vagy gyakrabban, esetleg rendszeresen írnak építészeti kritikát, mintha még mindig leírhatnák azt, amit több, mint tizenöt évvel ezelőtt Szilágyi Ákos írt le az irodalmi kritika állapotára vonatkozóan - csak az irodalom szót kell az építészet szóval helyettesíteni-eképpen : „Nem vagyok kritikus, mert nem lehetek kritikus. Nem lehetek kritikus, mert nincs valóságos építészeti élet, nincsenek igazi folyóiratok, nincsenek építészeti érdekek (legfeljebb létérdekek), nincsen semmi, amiért kritikussá lehetne vagy kellene lennie valakinek, akinek balvégzete úgy akarta, hogy építészettel foglalkozzék. Nincs építészet, csak múvek vannak. Nem vagyok kritikus, csak (építészeti) kritikákat írok.

De amikor egy múvet kritikai elemzésnek vetünk alá, akaratlanul is egy egész építészet látszatát keltjük, különben ugyanis nem lenne értelme a kritikának. Elképzelhető azonban, hogy maga a mủ árasztja egy új építészet szellemét, s ennek kritikai általánosítása elég hozzá, hogy szembeállítsuk azzal az építészettel, amely ugyan „van”, de nem „létezik”. A kérdés talán éppen az, hogyan érhető el, hogy egy kritikában ne a nem létező építészet visszhangozzék, ne az építészeti látszatvilág nyüzsgése verődjön vissza, hanem egy valóságos építészeti életé, amely még vagy már nincsen, de amely lehetne vagy kellene, hogy legyen. Ám az építészetnek mint intézménynek az állapota nem az egyes alkotók „,helyes” vagy „helytelen" tudatától függ" [9]. 


\section{IRODALOMJEGYZÉK}

[1] Walter Benjamin: A német szomorújáték eredete; Ismeretkritikai előszó. In: Angelus Novus, Budapest, Magyar Helikon, 1980. 195-232.

[2] Poszler György: A szépség és a felé mutató csillagok; Hat tézis a Kritika esélyeiről. in: Vonzások és taszitások. Bdapest, Liget, 1994. 106-107.

[3] Németh Lajos: A Kunstwollen zavara (Tartóshullám). Budapest, 1985. 107-110.

[4] Jean Baudrillard: Az érték sorsa. In: Az utolsó elötti pillanat (A közönyös paroxista) - Beszélgetések Philippe Petit-vel. Budapest, Magvető, Lassuló idő 2000, 9.

[5] Fülep Lajos: Célszerüség és müvészet az építészetben (a II. rész Töredékei) - közreadta: Tímár Árpád. Ars Hungarica, 1985/1, 132.

[6] Uo.

[7] Hans-Georg Gadamer: A szép aktualitása - A művészet mint játék, szimbólum és ünnep (1974). In: A szép aktualitása. Budapest, T-Twins kiadó, 1994. 52. és 56.

[8] Németh Lajos: A műinterpretáció kérdéseiről. Ars Hungarica, 1985/1, 19.

[9] Szilágyi Ákos: Nem vagyok kritikus! In: Nem vagyok kritikus! Budapest, Magvető Kiadó, 1984. 367.

\section{ABOUT ARCHITECTURAL CRITICISM}

\section{Summary}

As a result of deterioration of sensus communis, common perception, taste truth and beauty together with goodness became independent, and "clearness" of poetry was questioned and expressing power of words and forms gradually seem to be lost. In this utterly uncertain situation there seems to be only one chance for author and critique: make an effort for authenticity, knowing that all the compositions and all the possible evaluations and interpretations demand it, as after "the history of being forgotten" has ended - as Heidegger says - almost all that earlier only used to be "tasks" become problems.

Referring all this to the national architecture and national architectural way of thinking we can state that the absence of critical thinking that would be the starting point to possible theories can be extremely felt. Sharply stated: if it were only "tasks" in the national architecture to be solved (Lajos Fülep) and no "problems" to be thought through and to be solved. Identifying this absense is also missing. We can also feel that showing this state of absence as a problem is not missing for the profession of architecture.

Keywords: architectural criticism, architectural theory 